\title{
ANOTASI BIBLIOGRAFI
}

\section{Penggunaan Media Pembelajaran Smartphone,Sejarah Pendidikan Indonesia,Penerapan (TBLA) Pembelajaran Sejarah,}

Oleh

\section{Muhammad Sabirin}

Email : $1910111310017 @$ mhs.ulm.ac.id

Program Studi Pendidikan Sejarah Fakultas Keguruan dan Ilmu Pendidikan

Universitas Lambung Mangkurat

Banjarmasin

Susanto,H., \& Akmal,H. (2018).Efektivitas Penggunaan Aplikasi Pembelajaran Berbasis Mobile Smartphone Sebagai Media Pengenalan Sejarah Lokal Masa Revolusi Fisik di Kalimantan Selatan Pada Siswa Sekolah Menengah Atas,HISTORIA : Jurnal Program Studi Pendidikan Sejarah,6(2),197-206

Artikel ini mengkaji pembelajaran dengan media yang berbasis Mobile Smartphone dan memperkenalkan materi kepada pelaku sejarah lokal,tentang "Masa Revolusi Fisik di Kalimantan Selatan “.Pembahasan yang termuat dalam artikel ini menjelaskan bagaimana masa perubahan Fisik anak Remaja yang berubah dari belum mengenal teknologi dan dapat menerima efektif suatu materi sejarah lokal yang saling berhubungan dengan teknologi.Banyak informasi yang termuat di dalam artikel ini yang mengatakan efektifnya media yang di gunakan untuk pembelajaran di sekolah menengah atas.

Syaharuddin, S., \& Susanto, H. (2019).Sejarah Pendidikan Indonesia (Era Pra Kolonialisme Nusantara sampai Reformasi).

Artikel ini mengkaji tentang sistem pendidikan Indonesia,yang berkembang sampai denganya era kontemporer.Artikel ini mengupas cerita tentang awal adanya Pendidikan,suatu pendidikan dimasa silam berhubungan erat dengan sistem religious.Dalam pembahasa artikel ini memaparkan suatu terciptanya pengajaran dan pendidikan,dan adanya suatu masa ketika pendidikan dijadikan alat untuk berinteraksi dengan orang baru,artikel ini erat kaitanya pengeluaran kata kata yang sulit di pahami tentang tertanya materi.Dalam artikel ini banyak membahas jalur penyebaran pendidikan ke tempat orang yang belum mengetahuinya.dan adanya problem dari luar pendidikan berubah kondisi secara tak Nampak,dalam artikel ini banyak memaparkan pembagian jenis pendidikan.dan pembahasan yang lebih tertarik ialah adanya perkembangan pendidikan Indonesia yang sangat konherensif untuk suatu bahan ajaran. Artikel ini 
secara jelas memberitahukan masa-masa Pendidikan pada waktu yang berbeda.Kami rasa penjelasan yang termuat dalam artikel ini cukup luas dan secara jelas untuk diri pribadi.

Mutiani,M., WARMANSYAH ABBAS,E .R.S.I.S.,Syaharuddin,S.,\& Susanto,H (2019).Penerapan Transcript Based Lesson Analyses Pembelajaran Sejarah Di Sma Negri 7 Bnajarmasin.

Artikel ini mengkaji tentang pendekatan yang dilakukan dengan menerapkan Transcript Based Lesson Analyses untuk menunjang pembelajaran sejarah di SMA terkhus SMA 7 Banjarmasin,Bnayak cara pendekatan yang di pakai dalam Artikel ini,Artikel ini mengambarkan hasil penelitian yang terperinci dan cara pendekatan yang di pakai tenaga pendidik.Tersusunya sitematis yang di perlukan untuk penelitian,adanya metode yang jelas untuk penelitian, serta hasil dan pembahasan mengenai instansi terkait,Artikel ini memberikan gambaran yang jelas table informasi data yang ada.adanya dampak,kendala implementasi lesson study,yang sering di gunakan pihak lain.terdapat 2 tema disampaikan,pendekatan kooferarif menjadi siklus pendekatan yang dilakukan.adanya keberhasilan melalui model Transcript Based Lesson Analyses.Dalam artikel ini menjabarkan awal mula penelitian untuk pembelajaran sejarah yang ada di SMA dan sangat jelas menjabarkan rankaian kegiatan yang ada,serta memberikan hasil yang pasti.

\section{Simpulan Konseptual Anotasi Bibliografi}

Pembelajaran adalah hal yang wajib setiap orang rasakan meskipun mengunakan media apapun,ketika berkembangnya zaman dan teknologi,manusia di permudah dalam menuntut ilmu terkusus ilmu sejarah dan semakin berkembang teknologi,semakin pesat informasi yang di sebarkan lewat media smatfhone online maka akan semakin cepat mobilasasi jangkauan pembelajaran sejarah ke tempat tempat yang sulit di jangkau jasa guru/tenaga pendidik.

Pendidikan adalah kuncinya suatu perkembangan dan keberhasilan seseorang,sehingga sejarah pendidikan yang di bahas sangatlah bermanfaat menambah wawasan serta pengalaman dulu,tentang pentingnya pendidikan untuk masa akan dating,akan tetapi banyak yang kurang memahami tentang arti pendidikan sehingga banyak kasus yang terjadi,dan bagaimana peran siswa/mahasiwa untuk mengerti akan pentingnya pendidikan untuk suatu bangsa dan Negara.

Kajian yang sangat menarik untuk di telaah dan di pelajari lanngkah langkah dalam suatu kasus pengajaran sejarah agar dapat mengerti dan secara sadar berkomonikasi dengan baik antara siswa dan guru yang di bantu oleh pendekatan kooferatif,dan pentingnya pendakatan agar pembelajaran sejarah yang di rencanakan dapat berjalan dengan baik dan sesuai kesepakatan.dan penerapan yang di laksanakan mendapatkan keberhasilan oleh pihak terkait dan lembaga yang membantu. 